\title{
A Review of Solar Energy - Challenges, Economics \& Policies in India
}

\author{
Arun Kumar Singh Tomar ${ }^{1}$, K. K. Gautam ${ }^{2}$ \\ ${ }^{1,2}$ Rustamji Institute of Technology, BSF Academy, Tekanpur, Gwalior (M.P.)-475005
}

\begin{abstract}
In recent years the solar energy technologies has experienced phenomenal growth. The realization of technological improvements, growing public awareness of environmental issues, the economic climate and number of policy instruments have facilitated and sustained this strong interest in these technologies. Solar energy in one form or another is the source of nearly all energy on the earth. Humans, like all other animals and plants, rely on the sun for warmth and food. However, people also harness the sun's energy in many other different ways. For example, fossil fuels, plant matter from a past geological age, is used for transportation and electricity generation and is essentially just stored solar energy from millions of years ago. Solar energy has experienced phenomenal growth in recent years due to both technological improvements resulting in cost reductions and government policies supportive of renewable energy development and utilization. This paper provides an overview on solar energy in India. The paper also focuses on the technical and economical barriers and challenges for development and utilization of solar energy technology.
\end{abstract}

Keywords: solar energy, renewable energy, challenges, economics, policies

\section{Introduction}

Source of reliable renewable energy production and development become a major challenge to the most of the part of the world. For human development renewable energy source specially solar power can have positive effect, since energy is one of the important factor for the development of country as well as individuals, also as we all know that many other renewable energy plants are of large scale. During the past few years, a significant trust has been given to the development and induction of solar energy technology for use in different sectors. Solar power can be harnessed in two ways, in the form of heat (or thermal energy), and in the form of light energy. The light rays of solar energy are harnessed for power generation through solar cells and are called Photovoltaic (SPV) systems, where light is directly converted into electricity using silicon (solar) cells. The electricity thus generated can be used for lighting or other electrical applications. For the development of country energy sector plays an important role [1]. Power Generation has always been a challenge to the modern world. The status of a country's development is proportional to its energy consumption. India is the fourth largest energy consumer in the world after the United States, China, and Russia. In future, India and China will account for the biggest share of Asian energy demand growth through 2035[2]. Electricity is very important for any country for urbanization, industrialization, economic growth and improvement of living standard of society. India was the first country in the world to set up a Ministry of non- conventional energy resources in early 1980 . India is ranked fifth in the electricity generation in the world [3]. Presently, India has installed capacity of $276.783 \mathrm{GW}$ out of which $69.6 \%$ is from thermal, $15.2 \%$ from hydro, $2.1 \%$ from nuclear and about 13.2\% from renewable energy Sources (as on August 2015). Currently, the installed capacity of solar energy projects in India is about $4.22 \mathrm{GW}$. India is planning to produce 100 GW of solar power by 2022[4], [5]. Solar energy has experienced phenomenal growth in recent years due to both technological Improvements resulting in cost reductions and government policies supportive of renewable energy development and utilization. India is the only country in the world with an exclusive Ministry to promote the renewable energy sources. This paper analyzes the technical, economic barriers and policy aspects of solar energy development and deployment [6].

\section{Solar Energy in India}

India lies in the sunny belt of the world. India is endowed with vast solar energy potential. Most parts of India get 300 days of sunshine a year. About 5,000 trillion $\mathrm{kWh}$ per year energy is incident over Indian land area with most area receiving 4-7 kWh per sq. meter per day [7]. India is ranked 11th in solar power generation in the world as on Jan. 2014. Government funded solar energy in India only accounted for about $6.4 \mathrm{MW} / \mathrm{yr}$ of power as of 2005 . In 2010 capacity of 25.1MW was added and 468.3MW in 2011. In 2012 the capacity increase more than two times and become 1205 MW. During 2013 capacity added by 1114 MW and during 2014 capacity added by 313MW [8]. In August 2015, the installed grid connected solar power capacity is $4.22 \mathrm{GW}$. The price of solar energy has come down from Rs. 17.90 per unit in 2010 to about Rs.7 per unit in 2015. The Charanka Solar Park [9], at current installed capacity of $224 \mathrm{MW}$ is the largest Solar Park in Asia, was commissioned on April 19, 2012[10]. Some solar power plant of India is shown in the Table 1.

Table 1: Some solar plants of India

\begin{tabular}{|c|c|c|}
\hline Name of Plant & $\begin{array}{c}\text { Peak Power } \\
\text { (MW) }\end{array}$ & $\begin{array}{c}\text { Commission } \\
\text { Year }\end{array}$ \\
\hline $\begin{array}{c}\text { Charanka Solar Park, Charanka village, } \\
\text { Patan, Gujarat . }\end{array}$ & 224 & April 2012 \\
\hline $\begin{array}{c}\text { Welspun Solar MP project, } \\
\text { Neemuch,(M.P.) }\end{array}$ & 151 & March 2013 \\
\hline $\begin{array}{c}\text { Mahagenco Solar Project, Maharashtra } \\
\text { (M.P.) }\end{array}$ & 130 & March 2013 \\
\hline $\begin{array}{c}\text { Rajgarh Solar PV (NTPC),Rajghar } \\
\text { Welspun Energy Rajasthan Solar Project } \\
\text { Phalodhi, Rajasthan }\end{array}$ & 50 & March 2014 \\
\hline $\begin{array}{c}\text { Talcher Kaniha Solar PV (NTPC), } \\
\text { Odisha }\end{array}$ & 10 & March 2014 2013 \\
\hline Unchahar Solar PV(NTPC),(U.P.) & 10 & March 2014 \\
\hline
\end{tabular}




\section{International Journal of Science and Research (IJSR) \\ ISSN (Online): 2319-7064 \\ Index Copernicus Value (2015): 78.96 | Impact Factor (2015): 6.391}

In India, Rajasthan has the largest share of solar power generation of $28.4 \%$ and Gujarat share is $24.4 \%$ as on September 2015[11]. Table 2 shows current solar power capacity in different state of India.

Table 2: Current solar power capacity in some state as on September 2015[12]

\begin{tabular}{|c|c|c|}
\hline S.No. & State or U.T. & Capacity in $M W$ \\
\hline 1 & Andhra Pradesh & 279.44 \\
\hline 2 & Arunachal Pradesh & 0.265 \\
\hline 3 & Chhattisgarh & 73.18 \\
\hline 4 & Gujarat & 1000.05 \\
\hline 5 & Haryana & 12.8 \\
\hline 6 & Jharkhand & 16 \\
\hline 7 & Karnataka & 104.22 \\
\hline 8 & Kerala & 12.025 \\
\hline 9 & Madhya Pradesh & 673.58 \\
\hline 10 & Maharashtra & 378.7 \\
\hline 11 & Orissa & 56.92 \\
\hline 12 & Punjab & 200.32 \\
\hline 13 & Rajasthan & 1199.7 \\
\hline 14 & Tamil Nadu & 157.98 \\
\hline 15 & Telangana & 72.25 \\
\hline 16 & Tripura & 5 \\
\hline 17 & Uttar Pradesh & 71.26 \\
\hline 18 & Uttarakhand & 5 \\
\hline 19 & West Bengal & 7.21 \\
\hline 20 & Andaman \& Nicobar & 5.21 \\
\hline 21 & Delhi & 6.712 \\
\hline 22 & Lakshadweep & 0.75 \\
\hline 23 & Puducherry & 0.025 \\
\hline 24 & Chandigarh & 5.041 \\
\hline 25 & Daman \& Diu & 0.25 \\
\hline 26 & Others & 0.79 \\
\hline & Total & 4346.818 \\
\hline
\end{tabular}

\section{Benefits of Solar Energy}

1) Solar energy is a clean, renewable resource that is continuously supplied to the earth by the sun.

2) Solar resources are available everywhere in the world. It gives out no emissions i.e. environmentally safe.

3) Energy security to the country. No dependency on foreign resources for electricity generation.

4) Can be permitted and installed faster than other traditional or renewable power plants.

5) Produces local, on-site energy, which reduces the need for extensive high-voltage transmission lines or a complex infrastructure.

6) Reliable over the long term. With no moving parts, fixed photovoltaic systems last longer than other energy sources.

7) Clean, quiet and visually unobtrusive in nature. Solar energy plants do not have any polluting emissions, do not make any sound, and are not considered to be an "eyesore."

8) Creates clean, renewable energy that will sustain and support the health of future generations [6].

\section{Barriers \& Challenges of Solar Energy}

Various barriers and challenges on solar energy in India have been pointed below.
1) The efficiency constraint is one of the main barriers to widespread use. The thin-film and crystalline-silicon modules have efficiency ranges of $7 \%$ to $10 \%$ and $12 \%$ to $18 \%$ respectively. Even as PV technologies with significantly higher efficiencies are under development, the present efficiency ranges constitute a barrier .

2) In the case of solar thermal parabolic trough systems, one of the most proven solar power technology, the upper process temperature is limited by the heat carrying capacity of the thermal oil used for heat transfer. Thermal loss from heat storage in such system remains an important technical challenge in solar thermal technologies [6].

3) Per capita land availability is a scarce resource in India. Dedication of land area for exclusive installation of solar cells might have to compete with other necessities that require land. The amount of land required for utility-scale solar power plants - currently approximately $1 \mathrm{~km}^{2}$ for every 20-60 megawatts (MW) generated could pose a strain on India's available land resource [13].

4) Storage problem is also very serious. Suppose if the demand of power is not so high then the electricity produced by the solar plant will have to be stored somewhere to supply when demanded. This increases the cost of the project .

5) $100 \mathrm{GW}$ of solar would mean about $10.5 \%$ share for solar power in total generation of power in India. Such large share of intermittent sources requires huge investments in the power grid infrastructure for transmission smart supply and demand management [14].

6) To achieve a capacity of $60 \mathrm{GW}$ for utility scale projects by 2022 , there would be a requirement of about $\$ 40$ billion. The government currently expects a big share of this to come from international sources. But an international fund for solar projects in India is very less [15].

\section{Energy and Economic Development}

For social as well as economical development of a country power sector plays an important role. However for the development it is essential to improve efficiency of the energy generation and avoiding too much dependency on fossil fuels, as the use of fossil fuel plays a key role for pollution and undesirable change in climate conditions. The power sector is the essential part of a country's economy as well as it contain the interaction of demand and supply of energy. Almost every economic activity requires energy. For the continuous production and final consumption supply of energy is essential need, hence enhancement of power sector is important for the economic development. But the economic factors like prices of energy, costs of capital, infrastructure etc affect the development and enhancement new technologies of power generation system. In concern to the environment, demands of energy should be combined with the affect on ecological system locally as well as globally. Hence the economical and environmental factors are considered in the planning and preparation of the energy generation to meet the demand of energy for the development of that region. India faces a significant challenge in providing access to adequate, affordable and clean sources of energy, especially cooking fuel to a large section of the population, most of who live in rural areas 


\section{International Journal of Science and Research (IJSR) \\ ISSN (Online): 2319-7064 \\ Index Copernicus Value (2015): 78.96 | Impact Factor (2015): 6.391}

[16]. Solar energy is also a sustainable source of energy which is produced without any type of pollution, green house effect or other affect to the environment. The development of low cost solar technologies can be a potential alternative with distributed energy generation consisting of a cluster of local grid of electricity network. It could be a cheap and environment friendly alternative to the centralized power grid system having long distance, expansive wires delivery system. Fuel consumption in the vehicles can be reduced by using solar panel for air conditioning purpose [17].

\section{Indian Government Incentives Promotional Policies}

\subsection{Incentive mechanisms}

Because the point of grid parity has not yet been reached in many parts of the country, solar generating stations need some form of financial incentive to compete for the supply of electricity. Many states have introduced such incentives to support the deployment of solar power stations. Another form of indirect incentive which has been used to stimulate investment in solar power plant was tax credits available to investors. In some cases the credits were linked to the energy produced by the installations, such as the Production Tax Credits. In other cases the credits were related to the capital investment such as the Investment Tax Credits [6].

\subsection{Solar mission}

Jawaharlal Nehru National Solar Mission (JNNSM) was launched in 11 Jan. 2009 with the target for Grid Connected Solar Projects of 20,000 MW by 2022[18]. The Mission had adopted a three-phase approach. First four year (2009-13) had marked as Phase-I. The remaining 4 years of the twelfth Plan (2013-17) had been marked as Phase-II and the thirteenth Plan (2017-22) will be Phase-III of the project .The aim of this project was to add 1,000 MW of grid solar power by 2013 , and another $3,000 \mathrm{MW}$ by $2017[19]$. The target for 2017 may be higher based on the availability of international funds and technology transfer [20]. But in June 2015 The Union Cabinet of India gave approval for stepping up of India's solar power capacity goal under the Jawaharlal Nehru National Solar Mission (JNNSM) by five times, reaching $100 \mathrm{GW}$ by 2022 . The target will comprise of 40 GW rooftop and $57 \mathrm{GW}$ through large and medium scale grid connected solar power plants [21], [22], [23].

\subsection{Government Support}

The Government of India is providing Rs. 15,050 cr. subsidy to promote solar capacity addition in the country. This capital subsidy will be provided for solar projects in many cities and towns. Solar power projects with investment of about Rs. 90,000 cr. would be developed using bundling method with thermal power [22]. Further, investment will come from large Public Sector Undertakings (PSU) and Independent Power Producers (IPPs). Many states Government have also come out with state solar Policies to promote solar energy technology.

\subsection{Government acts and policies:}

Government of India has come out with Acts and Policies to support renewable Energy [24].

- The Electricity Act 2003 has promotes electricity generation from co-generation and renewable energy sources. This Act accelerated the process of renewable energy development in the country. The guidelines for competitive procurement have been framed under Section 63 of the Electricity Act 2003 it states:

- The Appropriate Commission shall adopt the tariff if such tariff has been determined through transparent process of bidding in accordance with the guidelines issued by the Central Government" [25].

- The National Electricity Policy 2005 stipulates that the share of electricity from non- conventional resources would need to be increased such purchase by distribution companies shall be through competitive process [26].

- -According to Tariff Policy 2006 states the Appropriate Commission shall decide a minimum percentage for purchase of energy [27]

\section{Conclusions}

Physically, solar energy constitutes the most abundant renewable energy resource available and, in most regions of the world, its theoretical potential is far in excess of the current total primary energy supply in those regions. Solar energy technologies could help address energy access to rural and remote communities help improve long-term energy security and help greenhouse gas mitigation.

In this paper, we have discussed about the current status of solar energy in India. The Ministry of non- convection energy resources, government of India is trying to increases the power capacity and achieve the target of $100 \mathrm{GW}$ by 2022. This discussion shows that the status of solar energy is satisfactory in India but some extra effort is required for betterment of solar source. Such efforts may require revisiting role and mandate of Jawahar Lal Nehru Solar Mission (JNNSM) and to position an institution that can lead new initiatives in solar resources assessment and technology development.

\section{References}

[1] Prof. (Dr) A K Ojha, Gaurav Kumar Gaur, Dr Santosh Kumar, Dr L P Singh" Solar Energy and Economic Development In India: A Review", International Journal of Emerging Technology and Advanced Engineering (ISSN 2250-2459), Volume 4, Special Issue 1, February 2014.

[2] Venkatakrishnan, G. R. and Dr. Rengaraj R. - verview of solar energy in India", International Journal of Development Research(IJDR) Vol. 4, Issue, 3, pp. 605-608, March, 2014.

[3] Load Generation and Balance Report, Central Electricity Authority, Ministry of Power, Government of India. Central Electricity Authority. 2015-16.

[4] Renewable Energy in India: Growth and Targets Ministry of New and Renewable Energy (MNRE), Government of India. 2015. 


\section{International Journal of Science and Research (IJSR) \\ ISSN (Online): 2319-7064 \\ Index Copernicus Value (2015): 78.96 | Impact Factor (2015): 6.391}

[5] Vikas K , et al. Status of solar wind renewable energy in India. Renewable and Sustainable Energy Reviews, 27:1-10, 2013.

[6] Ashok Upadhyay , Arnab Chowdhury - Słar Energy Fundamentals and Challenges in Indian restructured power sector" International Journal of Scientific and Research Publications, Volume 4, Issue 10, October 2014.

[7] Amita U and Soni MS. Concentrating solar power Technology, potential and policy in India. Renewable and Sustainable Energy Reviews, 15:5161-5175, 2011.

[8] Atul S. A comprehensive study of solar power in India and World. Renewable and Sustainable Energy Review, 15:1767-1777, 2011.

[9] Power Sector at a Glance all India, Ministry of Power, Government of India., 2015.

[10]A Discussion Paper, Barriers to Development of Renewable Energy in India \& Proposed Recommendation. Infrastructure Development Finance Company Ltd., 2010.

[11] Jawaharlal Nehru National Solar Mission, Press Information Bureau. Ministry of New and Renewable Energy, Government of India.

[12] State wise installed solar power capacity, Ministry of New and Renewable Energy, Government of India.

[13] Swami Prakash Srivastava, Surat Prakash Srivastava,"Solar energy and its future role in Indian economy", International Journal of Environmental Science: Development and Monitoring (IJESDM) ISSN No. 2231-1289, Volume 4 , No. 3 , 2013.

[14] Rachit S, Vinod KG" Solar Power - Current Status, Challenges and Policies in India", Research \& Reviews: Journal of Engineering and Technology ISSN: 23199873, 2016.

[15] https://en.wikipedia.org/wiki/Solar power in India.

[16] Ministry's Strategic Plan for Growth of Renewable Energy in India.

[17] http://en.wikipedia.org/wiki/Renewable energy in India/.

[18] Lolla S and Roy SB. Wind and Solar Resources in India. Energy Procedia. 70:187-192, 2015.

[19] Ishan P and Pallav P. Techno-economic evaluation of concentrating solar power generation in India. Energy Policy, 38:3015-3039, 2010.

[20] https://en.wikipedia.org/wiki/GujaratSolar Park.

[21] http://www.welspun.com/energy.asp

[22] Sharma BD. Performance of Solar Power Plants in India. Central Electricity Regulatory Commission New Delhi. 2011.

[23] Ongoing and Future Power Projects, Mahagenco Maharashtra State Power Generation Co. Ltd. Maharashtra.

[24] https://en.wikipedia.org/wiki/Grid parity

[25] Solar Energy in India, Solar Energy Association, TamilNadu.

[26] India Solar Handbook: Bridge to India. Bridge to India Energy Pvt. Ltd, India. 2015.

[27] Amita U and Soni MS. Concentrating solar power Technology, potential and policy in India. Renewable and Sustainable Energy Reviews, 15:5169-5175, 2011.

\section{Author Profile}

Arun Kumar Singh Tomar received the B.E.. from Maharana Pratap College of Technology, Gwalior, in Electrical Engineering and M.E. in Measurement \& Control from Madhav Institute of Technology and Science, Gwalior in 2006 and 2008, respectively. Presently, he is working as an Assistant Professor, Department of Electrical Engineering, in Rustamji Institute of Technology, BSF Academy, Tekanpur (M.P.).

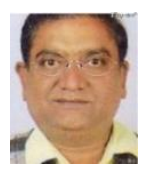

K.K. Gautam received the B.E. from Ravishankar University, Raipur, in Electrical Engineering and M.E. in Industrial System and Drives from Madhav Institute of Technology and Science, Gwalior in 1994 and 2011 respectively. He has long industrial and academic experience. Presently, he is working as an Assistant Professor, Department of Electrical Engineering, in Rustamji Institute of Technology.BSF Academy, Tekanpur (M.P.). 